Vasvári , Louise O. "English-Language Bibliography of Interest for Hungarian Cultural Studies: 2011-2012.“ AHEA: E-journal of the American Hungarian Educators Association, Volume 5 (2012): http://ahea.net/ejournal/volume-5-2012

\title{
English-Language Bibliography of Interest for Hungarian Cultural Studies: 2011-2012
}

\section{Louise O. Vasvári}

For a more extensive bibliography of Hungarian Studies from about 2000 to 2010, for which this is an update, see Louise O. Vasvári, Steven Tötösy de Zepetnek, and Carlo Salzani. "Bibliography for Work in Hungarian Studies as Comparative Central European Studies." CLCWeb: Comparative Literature and Culture (Library) (2011): http://docs.lib.purdue.edu/clcweblibrary/hungarianstudiesbibliography. As the title indicates, this bibliography covers the last year but it is supplemented by numerous earlier items that were not originally included in the large bibliography.

Adams, Bernard. 2010. “Translating Hungarian.” Anglistik 21.1: 131-140.

Allina-Pisano, Jessica. 2009. "From Iron Curtain to Golden Curtain: Remaking Identity in the European Union Borderlands." East European Politics and Societies 23.2: 266290.

Bak, János M, Martyn Rady, and Lászlo Veszprémy. 2010. Anonymous and Master Roger: The Deeds of the Hungarians and Epistle to the Sorrowful Lament Upon the Destruction of the Kingdom of Hungary by the Tatars. Budapest: CEU UP.

Bálint, Csanád. 2010. "Some Problems in Genetic Research on Hungarian Ethnogenesis,"Acta Archaeologica Acadeniae Scientiarum Hungariae, 61: 283-294.

Bernadett Csányi, Erika Bogácsi-Szabó, Gyönyvér Tömöry, Ágnes Czibula, Katalin Priskin, Aranka Csősz, B. Mende, P. Langó, K. Csete, A. Zsolnai, E. K. Conant, C. S. Downes and I. Raskó. 2008. "Y-Chromosome Analysis of Ancient Hungarian and Two Modern Hungarian-Speaking Populations from the Carpathian Basin." Annals of Human Genetics, 72: 519-534.

Bán, Zsofia. 2010. "The Turl Bird and the Dinosaur," Eurozine 11 http://www.eurozine.com/articles/2010-11-24-ban-en.html

Béres-Deák, Rita. 2011. “'I Was a Dark Horse in the Eyes of Her Family:' The relationship of Cohabiting Female couples and Their Families in Hungary." Journal of Lesbian Studies 3: 337-355.

Bálint, Csanád. 2010. "Some Problems in Genetic Research on Hungarian Ethnogenesis." Acta Archaeologica Acadeniae Scientiarum Hungaria 61: 283-294.

Bewes, Timothy \& Timothy Hull, eds. 2011. Georg Lukács: The Fundamental Dissonance of Existence: Aesthetics, Politics, Literature. New York: Continuum.

Blutinger, Jeffrey. 2010. "An Inconvenient Past : Post-Communist Holocaust Memorialization."Memorialization. » Shofar 29.1 : 73-93 http://www.scribd.com/doc/78490737/Blutinger-Post-Holocaust-H-Memorialization

Boode, Hanneke. 2011. "Keeping Up Appearances? Margit Kaffka's Short Fiction Narrators and Characters Revised." Gender Perspectives on Hungarian and Finnish Culture. Proceedings of the Workshop Gender Issues in Contemporary Finno-ugric Cultures. University of Groningen, June 3-4, 2010. Ed. Hanneke Boode and Edit Zsadányi. Maastricht: Shaker: 69-78. 
Vasvári , Louise O. "English-Language Bibliography of Interest for Hungarian Cultural Studies: 2011-2012.“ AHEA: E-journal of the American Hungarian Educators Association, Volume 5 (2012): http://ahea.net/ejournal/volume-5-2012

Boromisza-Habashi, David. 2007. "Freedom of Expression, Hate Speech, and Models of Personhood in Hungarian Political Discourse." Communication Law Review 7: 54-76. . 2011."Dismantling the Antiracist "Hate Speech" Agenda in Hungary: An Ethno-Rhetorical Analyis." Text and Talk 31: 1-19. . 2012. "The Cultural Foundation of Denials of Hungarian Hate Speech in Hungarian Broadcast Talk." Discourse and Communication 6: 3-20.

Böröcz, József. 2001. "The Fox and the Raven : The European Union and Hungary : Renegotiating the Margins of Europe." Central European Review 2001 http://www.cereview.org

Böröcz, József \& Melinda Kovács. 2001. Empire’s New Clothes. Unveiling EU Enlargement. Shropshire : Central European Review.

Bozóki, András. 2006. Anarchism in Hungary. Theory, History, Legacies. Wayne : Center for Hungarian Studies.

Braham, Randolph L. 2011. Bibliography of the Holocaust in Hungary. New York: East European Monographs.

Brubacker, Rogers, Margit Feischmidt, Jon Fox, and Liana Grancea. 2006. Nationalist Polities and Everyday Ethnicity in a Transylvanian Town. Princeton : Princeton UP.

Case, Holly. 2009. Between States. The Transylvanian Question and the European Idea During World War II. Stanford : Stanford UP.

Cole, Tim. 2006. "A Gendered Holocaust? The Experiences of Jewish Men and Women in Hungary, 1944." The Holocaust in Hungary: Sixty Years Later. Ed. Randolph L. Braham \& Brewster S. Chamberlin. New York: The Rosenthal Institute, Dist. By Columbia UP: 63- 75 http://www.theverylongview.com/WATH/essays/gendered.htm . 2008. "The Return of György András M.” Journal of Jewish Identities 1.2: $29-48$. . 2009. “1945: A Hungarian Year Nulla?” Journal of Contemporary History 44: 130-144. . 2011. Traces of Holocaust. Journeying In and Out of Ghettos. London: Continuum.

Cooper, Thomas. 2009. "Towards a Multilingual Concept of Culture : Romanian German Literature in Romanian and Hungarian Literature." Language Discourse and Identity in Central Europe. The German Language in a Multilingual Space. Ed. Jenny Carl \& Patrick Stevenson. 2009. New York : Palgrave-McMillan: 224-239.

Cornelius, Deborah. 2012. "The Impact of Trianon : Intellectual and Activist Movements of Hungarian Youth in the Detached Territories, 1920-1931." Hungarian Studies Review 21.1-2:75-91.

Csergö, Zsuzsa. 2007. Talk of the Nation: Language and Conflict in Romania and Slovakia. Ithaca: Cornell UP.

Csergö, Zsuzsa \& Kevin Deegan-Krause. 2011. "Liberalism and Cultural Claims in Central and Eastern Europe: Towards a Plural Balance." Nations and Nationalism 17.1: 85-107 http://www.la.wayne.edu/polisci/kdk/papers/nn2011.pdf 
Vasvári , Louise O. "English-Language Bibliography of Interest for Hungarian Cultural Studies: 2011-2012.“ AHEA: E-journal of the American Hungarian Educators Association, Volume 5 (2012): http://ahea.net/ejournal/volume-5-2012

Dreisziger, Nándor. 2012. "Misinformation, Disinformation or Pseudo-Science? István Kiszely's Quest for A Glorious Hungarian Past." Hungarian Studies Review 39.1-2: 137146. . 2009. "The Székelys: Ancestors of Today's Hungarians? A New Twist to Magyar Prehistory." Hungarian Studies Review 36.1: 153-160.

Durst, Péter \& Boglarka Janurik. 2011. "The Acquisition of the Hungarian Definite Conjugation by Learners of Different First Languages.” Lähivõdlusi/Lähivertailuja 21: 19-44.

Eklics, Kata. 2011."Female Interviewing Strategies in Hungarian Political Interviews." Gender Perspectives on Hungarian and Finnish Culture. Proceedings of the Workshop Gender Issues in Contemporary Finno-ugric Cultures. University of Groningen, June 34, 2010. Ed. Hanneke Boode and Edit Zsadányi. Maastricht: Shaker: 87-98.

Farkas, Tamás. 2008. "Surname Changes in Hungary: Researches and Their Onomastic Conclusions." Proceedings. 22nd International Congress of Onomastic Sciences. Pisa (Italy), 28.8-4.9.2005. 2. Ed. Maria Giovanna Arcamone, Davide de Camilli \& Bruno Porcelli. Pisa: Edizioni Ets: 343-350. . 2009. "Surnames of Foreign Origin in a Language Contact Situation. The Reasons and Ways of Their Changes and Their Influence in the Surname Stock. Names in Multi-Lingual, Multi-Cultural and Multi-Ethnic Contact. Ed. Wolfgang Ahrens, Sheila Embleton, André Lapierre.York: York UP. . 2008. "The Research of Official Family Name Changes in Hungary." Onomastica Uralica 7: 87-102. Debrecen-Helsinki. http://mek.oszk.hu/06800/06838

Farkas, Zita. 2006. "The Articulation of Lesbian Identities through the Paradigm of Visiblility and Invisibility in the Hungarian Context. Centre for Interdisciplinary Gender Studies http://www.gender-studies.leeds.ac.uk/assets/files/epapers/epaper32-zita-farkas.pdf

Fejez, Nárcisz \& Andrea P. Balogh, eds. 2012. Queer Visibility in Post-Socialist Cultures. Chicago: U of Chicago P.

Fenyvesi, Anna and Gyula Zsigri. 2011. "The Adaptation of English Initial Unstressed Syllables in American-Hungarian Loans. Theoretical Implications." Americana EJournal of American Studies in Hungary http://americanaejournal.hu/vol7ling/fenyvesizsigri

Frey, David S. 2005. "Just What is Hungarian? Concepts of National Identity in the Hungarian Film Industry, 1931-1944." Constructing Nationalities in East Central Europe. Ed. Pieter M. Judson and Marsha L. Rozenblitz. Oxford: Berghahn: 203-222.

Frojimovics, Kinga. 2003. "Jewish Naming Customs in Hungary from the Turn of the Twentieth Century until the Holocaust." The 23rd International Conference on Jewish Geneology. July 20-25, 2003, Washington DC. http://www.jewishgen.org/Hungary/2003nameskinga.html.

Gafijczuk, Darius. 2012. "Resonant Topographies: Central Europe's Paradoxical Middle." Theory, Culture and Society 29.3: 52-71.

Gal, Susan. 2003. "Movements of Feminism: The Circulation of Discourses About Women." Recognition Struggles and Social Movements. Contested Identities, Agency and Power. Ed. Barbara Hobson. Cambridge: Cambridge UP: 93-120. 
Vasvári , Louise O. "English-Language Bibliography of Interest for Hungarian Cultural Studies: 2011-2012.“ AHEA: E-journal of the American Hungarian Educators Association, Volume 5 (2012): http://ahea.net/ejournal/volume-5-2012

Gecsér, Ottó, József Lászlóvszky, Balázs Nagy, Marcel Sebők, Katalin Szende, eds. 2011. Promoting the Saints: Cults and their Contexts from Late Antiquity Until the Modern Period. Budapest: CEU P.

Gil, Isabel Capeloa. 2011. “A Question of Scale? Lászlo Almásy’s Desert Mapping and Its Postcolonial Rewriting.” Journal of Romance Studies 11.1: 63-77.

Gille, Zsuzsa. 2011. "The Hungarian Foie Gras Boycott: Struggles for Moral Sovereignity in Post-Socialist Europe." East European Politics and Societies 25: 114128. . 2009. "Globalizing Paprika: Food Governmentalities in the Postsocialist European Union." In Melissa Caldwell ed. Food and Everyday Life in Postsocialist Eurasia. Bloomington: Indiana UP: 97-128. . 2007. From the Cult of Waste in the Trash Heap of History: The Politics of Waste in Socialist and Postwar Hungary. Bloomington: Indiana UP.

Giordano, Alberto \& Tim Cole. 2011. "On Place and Space: Calculating Social and Spatial Networks in the Budapest Ghetto." Transactions GIS 15. Suppl. Issue: 143-170.

Glant, Tibor. 2007. Remember Hungary 1956. Essays on the Hungarian Revolution and War of Independence in American Memory. Boulder: Eastern European Monographs.

Gyarmati, György and Valuch, Tibor. 2009. Hungary under Soviet Domination 1944 1989. New York: Columbia University Press, Atlantic Research and Publications.

Hanebrink, Paul A. 2005. "'Christian Europe:' National Identity in Interwar Hungary." Constructing Nationalities in East Central Europe. Ed. Pieter M. Judson and Marsha L. Rozenblitz. Oxford: Berghahn. 192-202.

Haney, Lynne. 2002. "After the Fall: East European Women Since the Collapse of State Socialism." Contexts 1.3: 27-36.

Harretz, Maura E. "Gender in the Mosaic of the Habsburg Monarchy." Hungarian Studies Review 39.1-2: 127-132.

Hatoss, Anikó. 2006. "Community-Level Approaches in Language Planning. The Case of Hungarian in Australia." Current Issues in Language Planning 7.2-3: 287-306.

Hites, Sándor. 2012. "To Be Born into Exile. Kelemen Mikes and the $19^{\text {th }}-20^{\text {th }}$ Century Hungarian Literary Exiles." Hungarian Studies 26.2: 67-78.

Hobson, Barbara, Susanne Fahlen, \& Judit Takács. 2011. "Agency and Capabilities to Achieve a Work-Life Balance: A Comparison of Seden and Hungary." Social Politics 18.2: 168-198.

Horváth, Györgyi. 2011. "Women Authors With/Without Gender Studies: the Gendered Regimes of Authirity in Hungarian Literary Criticism Today. Gender Perspectives on Hungarian and Finnish Culture. Proceedings of the Workshop Gender Issues in Contemporary Finno-ugric Cultures. University of Groningen, June 3-4, 2010. Ed. Hanneke Boode and Edit Zsadányi. Maastricht: Shaker: 51-58.

Horváth, Sándor. 2011. "Wild West, Gangster, and Desperado Feelings. The Perception of the "West" in Youth Subcultures in Hungary in the 1960s." East Central Europe 38.23: $180-198$.

Horváth, Zsuzsa. 2011. "Rhetoric of Literary Genres in a Novel by Margit Kaffka." Gender Perspectives on Hungarian and Finnish Culture. Proceedings of the Workshop Gender Issues in Contemporary Finno-ugric Cultures. University of Groningen, June 34, 2010. Ed. Hanneke Boode and Edit Zsadányi. Maastricht: Shaker: 79-86. 
Vasvári , Louise O. "English-Language Bibliography of Interest for Hungarian Cultural Studies: 2011-2012.“ AHEA: E-journal of the American Hungarian Educators Association, Volume 5 (2012): http://ahea.net/ejournal/volume-5-2012

Hunyadi, Zsolt. 2010. The Hospitaliers in the Medieval Kingdom of Hungary, c. 1150 1387. Budapest: Department of Medieval Studies, Central European University. Imre, Anikó. 2007. "Hip Hop Nation and Gender Politics." Thamyris/Intersecting: Place, Sex, and Race 18: 265-85.

Imre Robert \& Zsuzsanna Millei. 2009. "Smashing Cosmopolitanism: The Neo-liberal Destruction of Cosmopolitan Education in East-Central Europe." Current Issues in Comparative Education 12: 76-85.

Jobbitt, Steven. 2008. "Subterranean Dreaming: Hungarian Fantasies of European Integration and Redemption in Nimród Antal's Kontroll," Kinokultura, Special Issue no. 7: Hungarian Cinema. www.kinokultura.com/specials/7/kontroll.shtml. . 2009. "Remembering Szatmár, Remembering Himself: The Geography of Memory and Identity in Ferenc Fodor's 'Szatmár Földje, Szatmár Népe, Szatmár Élete,"” Hungarian Studies Review XXXVI, Nos. 1-2: 15-38.

Jankovics, József. 2012. "Classicism and Neoclassicism in the Poetry of Mihály Babits." Hungarian Studies 26.1: 79-91.

Kádár, Judit. 2012. "Comparative Hungarian Cultural Studies.” Hungarian Studies Review 39.1-2: 157-162. . 2011. "Inclusion of Previously Banned Women Writers in the Hungarian Literary Canon after 1989." Gender Perspectives on Hungarian and Finnish Culture. Proceedings of the Workshop Gender Issues in Contemporary Finno-ugric Cultures. University of Groningen, June 3-4, 2010. Ed. Hanneke Boode and Edit Zsadányi. Maastricht: Shaker: 41-50.

Karády, Victor. 2000. "Self-Identification and Choice of Destiny. Studies in the History of Transformations of Jewish Identity in Hungary. Budapest: Új Mandátum.

Kálmán, György. 2012. "Strange Interferences: Modernism and Conservatism versus Avant-Garde, Hungary, 1910s." Hungarian Studies 26.1: 107-122.

Kenez, Peter. 2006. Hungary from the Nazis to the Soviets. The Establishment of the Communist Regime in Hungary, 1944-1948. New York: Cambridge University Press.

Kraft, Wayne. 2012. "Changing Traditions and Village Development in Kalotaszentkirály."Oral Tradition 26.2: 563-578 http://journal.oraltradition.org/issues/26ii/kraft\#myGallery-picture(7)

Krizsan, Andrea \& Raluca Popa. 2010. "Europeanization in Making Policies Against Domestic Violence in Central and Eastern Europe." Social Politics 17.3: 379-406.

Kürti, László. 2012. "Twenty Years After: Rock Music and National Rock in Hungary." Region 1.1: 93-130.

Laakso, Johanna. 2005. Our Otherness: Finno-ugrian Approaches to Women's Studies or Vice Versa. Berlin: Lit Verlag.

Laakso, Johanna, ed. 2008. Ungarischunterricht in Österreich. Teaching Hungarian in Austria. Berlin: Lit Verlag.

Ladányi, János. 2000. "The Hungarian Neoliberal State, Ethnic Classification and the Creation of a Roma Underclass." Poverty, Ethnicity and Gender in Eastern Europe During the Market Transition. Ed. Iván Szelényi and Rebecca Emigh: 67-82. Westport: Greenwood. 
Vasvári , Louise O. "English-Language Bibliography of Interest for Hungarian Cultural Studies: 2011-2012.“ AHEA: E-journal of the American Hungarian Educators Association, Volume 5 (2012): http://ahea.net/ejournal/volume-5-2012

Langman, Juliet \& István Lanstyák. 2000. "Language Negotiations in Slovakia: Views from the Hungarian Minority." Multilingua. Journal of Cross-Cultural and Interlanguage Communication 19.1/2: 55-72.

Lehócky Ágnes. 2011. Poetry, the Geometry of the Living Substance: Four Essays on Ágnes Nemes Nagy. Cambridge: Cambridge Scholars.

Levine, Paul. 2009. Raoul Wallenberg in Budapest: Myth, History and Holocaust. Portland: Vallentine Mitchell.

Maitz, Péter \& Klára Sándor. 2009. "Changes in the Linguistic Marketplace: The Case of German in Hungary. Language Discourse and Identity in Central Europe. The German Language in a Multilingual Space. Ed. Jenny Carl \& Patrick Stevenson. New York : Palgrave-McMillan: 149-164.

Medgyes, Péter and Katalin Miklósy. 2000. "The Language Situation in Hungary." Current Issues in Language Planning 1.2: 148-242.

Mecsnóber, Tekla. 2012. "Inbursts of Maggyer: Joyce, the Fal land the Magyar Language." Hungarian Studies 26.1: 93-106. . 2001. "James Joyce, Arthur Griffith, Triest and the Hungarian National Character." James Joyce Quarterly 38.3-4: 341-359 \& Focus: Papers in English Literature and Cultural Studies. Ed. Mária Kurdi \& Antal Bokay. Pécs: University, 2002: 30-40

Mevius, Martin. 2005. Agents of Moscow: The Hungarian Communist Party and the Origins of Socialist Patriotism 1941-1953. New York: Oxford University Press.

Michels, Georg B. 2012. "The 1672 Kuruc Uprising : A National or Religious Revolt." Hungarian Studies Review 39.1-2 : 1-20.

Miklódy, Éva. 2007. "A.R.T. Klikk, A.O.S. and the Rest: Hungarian Youth Rapping." Blackening Europe: The African American Presence. Heike Raphael-Hernandez, ed. New York: Routledge: 187-215.

Millei, Zsuzsanna \& Robert Imre. 2010. "Rethinking Transition through Ideas of 'Community' in Hungarian Kindergarten Curriculum." Post-Socialism Is Not Dead: (Re)Reading the Global in Comparative Education. Ed. Iveta Silova. Binkley: Emerald: 125-154.

Miller, Hillis J. 2012. “Imre Kertesz's Fatelessness: Fictions as Testimonies.” After Testimony: The Ethics and Aesthetics of Holocaust Narration for the Future. Ed. Jakob Lothe, Susan Suleiman, \& James Phelan. Columbus: Ohio State UP: 23-51.

Miller, Michael Laurence. 2010. "Going Native: Moritz Jellinek and the Modernization of the Hungarian Economy." Jewish History Encounters Economy. Ed. Gideon Reuveni New York: Berghahn Books: 158-173. . 2009. "From White Terror to Red Vienna: Hungarian Jewish Students in Interwar Austria." Wien und die jüdische Erfahrung 1900-1938: Akkulturation, Antisemitismus, Zionismus. Ed. Frank Stern. Vienna: Böhlau: 307-324.

Miron, Guy. 2011. The Waning of Emancipation: Jewish History, Memory, and the Rise of Fascism in Germany, France and Hungary. Detroit: Wayne State UP.

Morris, James Mcrath. 2010. Pulitzer: A Life in Politics, Print, and Power. New York: Harper. 
Vasvári , Louise O. "English-Language Bibliography of Interest for Hungarian Cultural Studies: 2011-2012.“ AHEA: E-journal of the American Hungarian Educators Association, Volume 5 (2012): http://ahea.net/ejournal/volume-5-2012

Nadkarni, Maya. 2010. "But It's Ours: Nostalgia and the Politics of Authenticity in Postsocialist Hungary." Post-Communist Nostalgia. Ed. Maria Todorova and Zsuzsa Gille. New York: Berghahn: 190-214. . 2007. "The Master's Voice: Authenticity, Nostalgia and the Refusal of Irony in Postsocialist Hungary." Social Identities 13.5: 611-26.

Nagy, Dóra, Gyöngyvér Tömöry, Bernadett Csanyi, Erika Bogácsi-Szabó, Ágnes Czibula, Katalin Priskin, Olga Bede, László Bartosiewicz, C. Stephen Downes, and István Raskó. 2011. "Comparison of Lactose Persistence Polymorphism in Ancient and Present-Day Hungarian Populations." American Journal of Physical Anthropology 145.2: 262-269.

Nagy, Térezia 2003. "The Appearance of an Underground Electro-Music Subculture in the Cultural Sphere of the City." Acta Ethnographica Hungarica 48.1-2: 123-38.

Nemes, Robert James. 2005. "The Revolution in Symbols: Hungary in 1848-1849." Constructing Nationalities in East Central Europe. Ed. Pieter M. Judson and Marsha L. Rozenblitz. Oxford: Berghahn. 37-49.

Palasik, Mária. 2012. "A Life Lived for Progress and Democracy: Sára Karig (1914 1999)." Hungarian Studies Review 39.1-2: 93-112.

Palosuo, Laura. 2008. "The Holocaust in Hungary. The Importance of Gender, Age, and Geography for Jewish Experience." http://www.theverylongview.com/WATH/essays/palosuo.htm

Papp, Susan. 2012. „Minority Hungarian Communities in the Twentieth Century.“ Hungarian Studies Review 39.1-2: 151-157.

Rákai, Orsolya. 2011. "The Fat Margin and the Canon: Modern and Late-Modern Aesthetics and Canonized Women Writers in the History of $20^{\text {th }}$ Century Hungarian Literary Criticism. Gender Perspectives on Hungarian and Finnish Culture. Proceedings of the Workshop Gender Issues in Contemporary Finno-ugric Cultures. University of Groningen, June 3-4, 2010. Ed. Hanneke Boode and Edit Zsadányi. Maastricht: Shaker, 2011: 30-40.

Rásky, Béla. 2007. "Eloquent Silence : Inscribing Hungarian Memories." Restitution of Memory : Material Restoration in Europe. Ed. Dan Diner \& Gotthart Wunberg. Oxford : Berghahn: 217-231.

Romsics, Ignac. 2007. From Dictatorship to Democracy: The Birth of the Third Hungarian Republic, 1988-2001. New York : East European Monographs, Distributed by Columbia UP.

Sakmyster, Thomas. 2012. "Hungary's Darkest Days (1939-1945)." Hungarian Studies Review 39.1-2: 113-120.

Scholz, László. 2011. "Squandered Opportunities: On the Uniformity of Literary Translations in Postwar Hungary." Contexts, Subtexts, Pretexts: Literary Translation in Eastern Europe and Russia. Ed. Brian James Baer. Amsterdam: Benjamins: 2005-217.

Schwarz, Agata. 2012. "The 1956 Revolution: Hungarian and Canadian Perspectives." Hungarian Studies Review 39.1-2: 147-151.

Schwarz, Agata. 2012. "Budapet and Its Heroines in Fin-de-Siècle Hungarian Literature." Hungarian Studies Review 39.1-2: 45-74.

Somogyváry, Lajos. 2012. "The Image, Concept and Language of the Rose: From Antiquity to the renaissanc." Hungarian Studies Review 39.1-2: 121-126. 
Vasvári , Louise O. "English-Language Bibliography of Interest for Hungarian Cultural Studies: 2011-2012.“ AHEA: E-journal of the American Hungarian Educators Association, Volume 5 (2012): http://ahea.net/ejournal/volume-5-2012

Szalai, Júlia. 2003. "Conflicting Struggles for Recognition: Clashing Interests of Gender and Ethnicity in Contemporary Hungary." Recognition Struggles and Social Movements. Contested Identities, Agency and Power. Ed. Barbara Hobson. Cambridge: Cambridge UP: 188-214. http://eucenter.wisc.edu/calendar/spring03/szalaiRecognition.pdf

Szegedy-Maszák, Mihály. 2012. "The Literary Canon of Ferenc Liszt.” Hungarian Studies 26.1: 123-140. .2012. "A Conversation Between Zoltán Kocsis and Mihály Szegedy-Maszák on the Oeuvre of Ferenc Liszt." Hungarian Studies 26.1: 141-161. . 2011. "The Status of the Woman Writer in Hungary. Gender Perspectives on Hungarian and Finnish Culture. Proceedings of the Workshop Gender Issues in Contemporary Finno-ugric Cultures. University of Groningen, June 3-4, 2010. Ed. Hanneke Boode and Edit Zsadányi. Maastricht: Shaker: 25-32.

Szelenyi, Balazs A. "The Dynamics of Urban Development: Towns in Sixteenth- and Seventeenth-Century Hungary." American Historical Review 109.2: 360-86.

Szemere, Anna. 2010. "The Velvet Prison in Hindsight: Artistic Discourse in Hungary in the 1990's." Post-Communist Nostalgia. Ed. Maria Todorov and Zsuzsa Gille. New York: Berghahn: 244-62.

Szentkirályi, Endre. 2010. "No Passport? Can’t Go Home! The Novels of Aron Gábor." Hungarian Quarterly 51: 139-145.

Simeziana, Sarah. 2010. "Roma Rap...Minority Voices in Hungarian Hip Hop." The Languages of Global Hip-Hop. Ed. Marina Terkou-Rafi. London: Continuum: 96-119.

Stanulescu, Manuela Sofia, and Tina Stanovnik. 2009. Activity, Incomes and Social Welfare : A Comparison Across Four New EU Member States. Burlington : Ashgate.

Szőnyei, Tamás. 2011. "Kept on File: the Secret Service's Activities Against Popular Music in Hungary, 1960-1990." Journal of East Central Europe 38.2-3: 199-220.

Todorova, Maria. Ed. 2010. Communism: Genres of Representation. New York: Social Sciences Research Council.

Todorova, Maria \& Zsuzsa Gille, eds. 2010. Post-Communist Nostalgia. New York: Berghahn.

Tolcsvai, Gábor. 2011. "Mother, Woman: Linguistic Images by Péter Esterházy." Gender Perspectives on Hungarian and Finnish Culture. Proceedings of the Workshop Gender Issues in Contemporary Finno-ugric Cultures. University of Groningen, June 34, 2010. Ed. Hanneke Boode and Edit Zsadányi. Maastricht: Shaker: 99-108.

Tömöry, Gyönyvér, Bernadett Csányi, Erika Bogácsi-Szabó, Tibor Kalmár, Ágnes Czibula, Aranka Csősz, Katalin Priskin, Balázs Mende, Péter Langó, C. Stephen Downes and István Raskó. 2007. "Comparison of Maternal Lineage and Biogeographic Analyses of Ancient and Modern Hungarian Populations." American Journal of Physical Anthropology. 134: 354-368.

Tóth, Edit. 2012. "TheArt of Andor Weininger in Transition." Hungarian Studies Review 39.1-2: 133-136.

Trencsényi, Balázs \& Apor, Péter. 2007. "Fine-Tuning the Polyphonic Past: Hungarian Historical Writing in the 1990s." Narratives Unbound: Historical Studies in PostCommunist Eastern Europe. Eds. Sorin Antohi, Balázs Trencsényi, \& Péter Apor. Budapest: Central European UP : 1-75. 
Vasvári , Louise O. "English-Language Bibliography of Interest for Hungarian Cultural Studies: 2011-2012.“ AHEA: E-journal of the American Hungarian Educators Association, Volume 5 (2012): http://ahea.net/ejournal/volume-5-2012

Vari, Alexander. 2006. "From Friends of Nature to Tourist-Soldiers: Nation Building and Tourism in Hungary, 1873-1914. Turizm; The Russian and Eastern European Tourist under Capitalism and Socialism. Ed. Anne Gorsuch and Diane Koenker. Ithaca: Cornell UP. . 2006. "Exile, Urban Tourism and Identity: Hungarian Travelers in Paris, 1918-1940." Journeys: The International Journal of Travel and Travel Writing 7.1: 81109. . 1999. "A Case of Female Hysteria in Hungary in the 1880s." Budapest Review of Books Winter 1999: 179-187.

Vida, István Kornél. 2012. Hungarian Emigres in the American Civil War: A History and Biographical Dictionary. Jefferson NC: McFarland.

Venkovitz, Balazs. 2011. "Describing the Other, Struggling with the Self: Hungarian Travel Writers in Mexico and the Revision of Western Images." Journeys 12.2: 28-47.

Vermes, Gábor. 2012. "Extra Hungariam Non Est Vita and the Baroque in the Eighteenth and Early Nineteenth Century Hungary." Hungarian Studies Review 39.1:21-34.

Von Papen-Bodek, Patricia. 2005. "The Hungarian Institute for Research into the Jewish Question and Its Participation in the Expropriation and Expulsion of Hungarian Jewry." Constructing Nationalities in East Central Europe. Ed. Pieter M. Judson and Marsha L. Rozenblitz. Oxford: Berghahn, 2005. 223-242.

Walker, Alan. 2012. "Franz Liszt: A bicentennial Tribute." Hungarian Studies Review 39.1-2: 35-44.

Waterbury, Myra. 2010. Betwee State and Nation: Diaspora Politics and Kin-State Nationalism in Hungary. New York: Palgrave MacMillan. . 2009. "From Irredentism to Diaspora Politics: States and Transborder Ethnic Groups in Intereurope." Global Migration and Transnational Politics Working Papers July 2009: http://cgs.gmu.edu/publications/gmtpwp/gmtp_wp_6.pdf

Weaver, Eric Beckett. 2012. "Hungarian Views of the Bunjevci in Habsburg Times and the Interwar Period." Balcanica. Annual of the Institute for Balkan Studies 42: http://www.doiserbia.nb.rs/img/doi/0350-7653/2011/0350-76531142077W.pdf . 2009. "Say It Softly : Hungarians Abroad and the Failure of the Center Right in Hungarian Elections." Nationalisms Today. Ed. Tomasz Kamusella \& Krysztof Jaskulowski. Oxford : Oxford UP : 71-88. . 2007. "The Communist Legacy ? Populist but Non Popular. The Foreign Policies of the Hungarian Radical Right." Europe for Europeans. The Foreign and Security Policy of the Populist Radical Right. Ed. Christina Schori Lang.Alderschot : Ashgate : 177-185. . 2002. "Madness in the Media in Countries in Transition : An Anthropological Appraisal with Marginal Notes on Publishing in Hungary and Serbia." RFE/RL East European Perspectives 4 : http://users.ox.ac.uk/ oaces/weaver.html

Zsadányi, Edit. 2011. "Reflecting Upon Non-Reflected Female Dependency." Gender Perspectives on Hungarian and Finnish Culture. Proceedings of the Workshop Gender Issues in Contemporary Finno-ugric Cultures. University of Groningen, June 3-4, 2010. Ed. Hanneke Boode and Edit Zsadányi. Maastricht: Shaker: 69-78. 